\title{
Statistical Comparative Petiol Anatomy of Salvia sp. ${ }^{1}$
}

\author{
Análise Comparativa da Anatomia do Pecíolo Salvia sp. \\ ÖZDEMİR, A. ${ }^{2}$ ÖZDEMİR, A.Y. ${ }^{3}$, and YETISSEN, K. ${ }^{2}$
}

\begin{abstract}
In this study, petiol anatomy of 17 Salvia sp. taxa were compared statistically. In all the studied taxa, some differences were found in the petiole shape, number of vascular bundles and the presence of chlorenchyma. Anatomical variations in 17 Salvia taxa have been investigated by means of numerical methods (Analysis of variance and Pearson correlation). By the analysis of the investigated taxa from 17 leaf anatomy related characters, it has been determined that epidermis width and trachea diameter are the best character pairs which represent the variations in them. It has been also found that the results from numerical analysis of the leaf anatomy characters can provide additional evidences that correspond to the anatomy for the recognition of the taxa.
\end{abstract}

Keywords: anatomy, Lamiaceae, Petiole, Salvia, Statistical analysis.

\begin{abstract}
RESUMO - Neste estudo, a anatomia do peciolo de 17 taxa de Salvia sp. foram comparados estatisticamente. Entre os taxa estudados, algumas diferenças foram encontradas na forma do peciolo, número de feixes vasculares e a presença de clorênquima. As variações anatômicas em 17 taxa de Salvia foram investigadas por meio de métodos numéricos (análise de variância e de correlação de Pearson). Através da análise dos taxa investigados de 17 caracteres relativos à anatomia foliar, foi determinado que a largura da epiderme e o diâmetro da traqueia são os melhores pares de caracteres que representam suas variações. Foi também constatado que os resultados da análise numérica dos caracteres da anatomia foliar podem fornecer evidências adicionais correspondentes à anatomia para a identificação dos taxa.
\end{abstract}

Palavras-chave: anatomia, Lamiaceae, pecíolo, Salvia, análise estatística.

\section{INTRODUCTION}

Lamiaceae is a large family. Most of the species are greatly relevant, due to their economic values. Lamiaceae is represented by about 258 genera and 3500 species in the world (Duarte and Lopes, 2007). Many of such species are used as raw material in the cosmetic industry. Some species are traditionally used as medicinal plants (Baytop, 1984). The genus Salvia sp. with over 900 species is probably the most commonly found member of the family Lamiaceae, in both subtropical and temperate parts of the world (Özdemir and Senel, 1999). The two largest centres of the genus are in America and in South-West Asia. Anatolia is a major centre for Salvia in Asia (Vural and Adigüzel, 1996). Since the most recent revision of the genus, three new species have been described; the total has now reached 97 (Davis, 1982; Davis et al., 1988; Güner et al., 2000; Dönmez, 2001; Dođan, 2008). 51 of Salvia species are endemic in Turkey and endemizm rate is $\mathbf{5 2 . 5}$ (Davis, 1982; Dođan, 2008). In recent years, anatomical characters have been used in taxonomy (Agbagwa and Ndukwu, 2004; Kharazian, 2007). The structure of petiole shows differences between genera and species. Thus, useful petiole anatomic

Recebido para publicação em 1.9.2015 e aprovado em 5.2.2016.

2 Celal Bayar University, Faculty of Art and Science, Manisa-Turkey; ${ }^{3}$ University of Rochester, Department of Economics, New York-USA.<kadriyeyetisen@gmail.com>. 
characters are determined in designated taxonomical structures of some species (Olowokudejo, 1987, Shaheen, 2007, Tepe et al., 2007; Akçin et al., 2011). Anatomical structures of the petiole are very important in family Lamiaceae (Metcalfe and Chalk, 1972). The petiols of Salvia taxa have a unique and distinctive shape in cross section.

The aim of this study was to investigate the anatomical structures and to evaluate as statistical of petioles of 17 Salvia taxa growing in Turkey (Table 1).

\section{MATERIAL AND METHODS}

Plant samples were collected from natural populations. Taxonomic description of the plant was made according to Davis, (1982). Anatomical works were carried out on the fresh samples preserved in $70 \%$ alcohol. Paraffin method was used for preparing cross sections of the tissues (Algan, 1981). For the numerical analysis, 5 characters of the petiol were selected. This selection was based on the variations of the petiol anatomical data. Characters were coded as 1, 2, 3, 4, 5 and the taxa were coded as A, B, C, D, E, F, G, H, I, J, K, L, M, N, O, P, R. Significance of the differences between the taxa and characters were evaluated by Analysis of variance (Regression Analysis) and Pearson correlation (Table 2).

\section{RESULTS AND DISCUSSION}

Salvia limbata C.A.Mey.: The outermost layer of the cross-section of petiole consists of epidermis cells squarish rectangular and oval in shape. Epidermis cells are $17-25 \mu \mathrm{m}$ in width and 12-18 $\mu \mathrm{m}$ in length. Parenchyma under epidermis has intercellular space and consists of 7-10 cell layers. Parenchyma cells are circular in shape and their diameter varies from $25-70 \mu \mathrm{m}$. A big vascular bundle is present in the center of cross-section of petiole. There are 2 small vascular bundles in the ends of the petiole. Type of vascular bundle is collateral. The central vascular bundle has $25-32$ xylem rays. Diameter of trachea is $10-23 \mu \mathrm{m}$.

Table 1 - Anatomical measurements of the Salvia taxa

\begin{tabular}{|c|c|c|c|c|c|c|}
\hline \multirow{2}{*}{\multicolumn{2}{|c|}{ Taxon }} & \multirow{2}{*}{$\begin{array}{c}1 \\
\text { Epidermis } \\
\text { width } \\
(\mu \mathrm{m}) \\
\text { Mean SD }\end{array}$} & \multirow{2}{*}{$\begin{array}{c}2 \\
\text { Epidermis } \\
\text { length } \\
(\mu \mathrm{m}) \\
\text { Mean SD }\end{array}$} & \multirow{2}{*}{$\begin{array}{c}3 \\
\text { Trachea } \\
\text { diameter } \\
(\mu \mathrm{m}) \\
\text { Mean SD }\end{array}$} & $\begin{array}{c}4 \\
\text { Parenchyma } \\
\text { width } \\
(\mu \mathrm{m})\end{array}$ & $\begin{array}{c}5 \\
\text { Parenchyma } \\
\text { length } \\
(\mu \mathrm{m})\end{array}$ \\
\hline & & & & & Mean SD & Mean SD \\
\hline $\mathbf{A}$ & S. limbata & $21.3 \pm 2.51$ & $13.9 \pm 1.70$ & $15.3 \pm 3.79$ & $43.2 \pm 10.6$ & $20.0 \pm 0.19$ \\
\hline B & S. huberi & $32.5 \pm 4.78$ & $24.7 \pm 4.44$ & $16.3 \pm 3.95$ & $54.7 \pm 5.06$ & $23.0 \pm 0.26$ \\
\hline $\mathbf{C}$ & S.verticillata ssp. verticillata & $24.0 \pm 2.77$ & $17.9 \pm 3.01$ & $16.61 \pm 3.58$ & $15.3 \pm 3.17$ & $32.3 \pm 4.53$ \\
\hline D & S. chrysophila & $22.9 \pm 1.22$ & $29.0 \pm 4.88$ & $17.1 \pm 4.18$ & $17.9 \pm 2.78$ & $22.2 \pm 3.21$ \\
\hline $\mathbf{E}$ & S.recognita & $15.0 \pm 3.29$ & $20.1 \pm 7.14$ & $10.5 \pm 2.51$ & $20.0 \pm 4.83$ & $12.0 \pm 0.13$ \\
\hline $\mathbf{F}$ & S. halophila & $30.6 \pm 4.09$ & $24.5 \pm 4.14$ & $20.5 \pm 5.21$ & $60.0 \pm 12.2$ & $7.90 \pm 0.86$ \\
\hline $\mathbf{G}$ & S. smrynaea & $26.2 \pm 6.51$ & $7.50 \pm 1.86$ & $13.1 \pm 3.34$ & $35.0 \pm 10.9$ & $20.0 \pm 0.19$ \\
\hline & S. tchihatcheffii & $12.3 \pm 1.98$ & $10.2 \pm 3.03$ & $9.00 \pm 3.97$ & $24.4 \pm 4.96$ & $20.0 \pm 0.19$ \\
\hline I & S. multicaulis & $29.0 \pm 11.9$ & $12.7 \pm 3.28$ & $20.3 \pm 5.28$ & $65.0 \pm 15.0$ & $15.0 \pm 0.11$ \\
\hline $\mathbf{J}$ & S. wiedemannii & $29.0 \pm 3.16$ & $14.3 \pm 3.45$ & $11.1 \pm 3.21$ & $30 \pm 14.09$ & $15.0 \pm 0.12$ \\
\hline $\mathbf{K}$ & S. suffruticosa & $15.0 \pm 2.35$ & $11.5 \pm 1.76$ & $12.9 \pm 2.79$ & $40.3 \pm 12.9$ & $27.1 \pm 3.80$ \\
\hline & S. verticillata ssp. amasiaca & $18.3 \pm 4.87$ & $13.9 \pm 1.23$ & $22.2 \pm 4.62$ & $16.4 \pm 2.79$ & $24.2 \pm 9.30$ \\
\hline $\mathbf{M}$ & S. bracteata & $33.5 \pm 6.30$ & $28.0 \pm 3.94$ & $26.4 \pm 4.07$ & $71.6 \pm 12.4$ & $14.8 \pm 5.90$ \\
\hline $\mathbf{N}$ & S. cadmica & $39.3 \pm 6.27$ & $20.0 \pm 3.27$ & $20.4 \pm 10.6$ & $57.1 \pm 33.8$ & $21.5 \pm 3.83$ \\
\hline $\mathbf{O}$ & S. blepharochlaena & $20.4 \pm 3.79$ & $21.1 \pm 1.9$ & $14.7 \pm 4.87$ & $34.2 \pm 10.3$ & $12.3 \pm 2.17$ \\
\hline $\mathbf{P}$ & S. microstegia & $26.5 \pm 8.95$ & $18.9 \pm 4.29$ & $11.2 \pm 2.50$ & $24.8 \pm 5.98$ & $14.9 \pm 1.78$ \\
\hline & S. cryptantha & $25.0 \pm 9.03$ & $19.8 \pm 4.05$ & $11.7 \pm 2.78$ & $27.7 \pm 6.83$ & $12.2 \pm 1.21$ \\
\hline
\end{tabular}

SD: Standart Deviation. 1-5: Character Codes. A-R: Taxon Codes. 


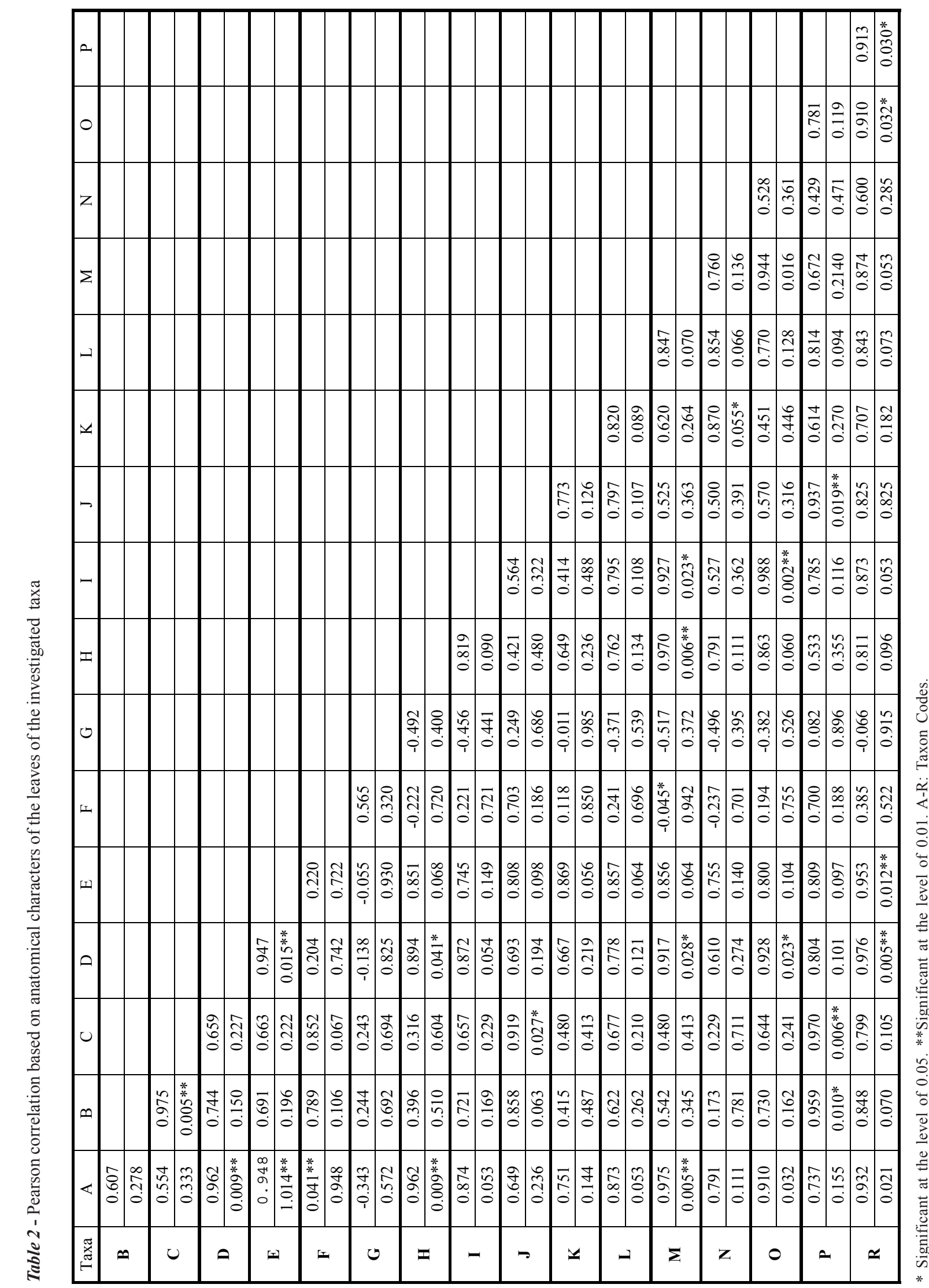


S. huberi Hedge: The one layered epidermis cells shaped in squarish rectangular and oval. Epidermis cells are $25-40 \mu \mathrm{m}$ in width and $17-33 \mu \mathrm{m}$ in length. Intercellular spaces absent in 6-8 cell layered parenchyma under the epidermis. Parenchyma cells are circular in shape and have 45-73 $\mu \mathrm{m}$ diameter. A big vascular bundle is located in the center of crosssection of petiole, While 2 small vascular bundles in the ends of the petiole. The central vascular bundle has 20-22 xylem rays. Diameter of trachea is $14-22 \mu \mathrm{m}$.

S. verticillata ssp. verticillata (Freyn \& Bornm.) Bornm.: Epidermis cells are single layered, rectangular or oval shaped. Epidermis cells are $20-28 \mu \mathrm{m}$ in width and $12-23 \mu \mathrm{m}$ in length. Parenchyma under epidermis has intercellular space and consists of 10-13 cell layers. Parenchyma cells are roundish or rectangular in shape and $10-20 \mu \mathrm{m}$ in width, 22-40 in length. Multi-lobed (6), big vascular bundle is present at the center of the petiole. There is oval shaped vascular bundle in each corner. The central vascular bundle has 51-55 xylem rays. Diameter of trachea is 13-23 $\mu \mathrm{m}$.

S. chrysophila Stapf: Epidermis consist of single layered cell line shaped in squarish and rectangular. Epidermis cells are 21-26 $\mu \mathrm{m}$ in width and $20-35 \mu \mathrm{m}$ in length. There is a layered eksodermis on abaxial side of petiol. Intercellular spaces absent in 6-8 cell layered parenchyma under the eksodermis. Parenchyma cells are circular, oval in shape and have $12-23 \mu \mathrm{m}$ width and $17-28 \mu \mathrm{m}$ length. A big vascular bundle is located in the center of cross-section of petiole, while 4 small vascular bundles in the ends of the petiole and sheat cells present around this bundles. The central vascular bundle has $19-21$ xylem rays. Diameter of trachea is $10-28 \mu \mathrm{m}$.

S. recognita Fisch. \& Mey: Epidermis cells are single layered, rectangular or squarish shaped. Epidermis cells are $10-20 \mu \mathrm{m}$ in width and $8-33 \mu \mathrm{m}$ in length. There is a layered eksodermis on abaxial side of petiol as S. chrysophila. Parenchyma under epidermis consist of 6-11 cell layer. Parenchyma cells are circular or oval in shaped and $14-30 \mu \mathrm{m}$ in diameter. A big vascular bundle is present in the center and 4 small vascular bundles, surrounded by sheet cells, in the ends of the petiole. The central vascular bundle has $16-20$ xylem rays. Diameter of trachea is $7-15 \mu \mathrm{m}$.

S. halophila Hedge: Outermost layer of petiol consist of a leyered epidermis shaped in oval and rectangular. Epidermis cells are $20-38 \mu \mathrm{m}$ in width and $18-33 \mu \mathrm{m}$ in length. 6-9 lined parenchyma cells are circular and hexagonal in shape and have 35-105 $\mu \mathrm{m}$ diameter. A big vascular bundle is located in the center and 2 in the ends of the petiole. 16-18 xylem rays present in the central vascular bundle. Diameter of trachea is 10-33 $\mu \mathrm{m}$.

S. smrynaea Boiss.: Petiol is four-cornered and the corners jut out to outwards. Single layered wavy epidermis present in cross section of petiol. Epidermis cells are 17-43 $\mu \mathrm{m}$ in width and 5-12 $\mu \mathrm{m}$ in length. intercellular spaces absent in 4-7 cell layered Parenchyma which are oval, squarish and circular in shape and their diameter is $15-50 \mu \mathrm{m}$. A big vascular bundle is present in the center of cross-section of petiole and 4 small vascular bundles in the ends of the petiole. The central vascular bundle has 22-24 xylem rays Trachea, with a diameter 7-19 $\mu \mathrm{m}$.

S. tchihatcheffii Boiss.: Epidermis cells of the petiol single layered, shaped in squarish and rectangular. Epidermis cells are 10-16 $\mu \mathrm{m}$ in width and $8-14 \mu \mathrm{m}$ in length. There is a layered eksodermis under the epidermis. A 4-6 cell-layered parenchyma does not have not intercellular spaces. Parenchyma cells are circular hexagonal, oval in shaped and have $15-38 \mu \mathrm{m}$ in diameter. A big vascular bundle is located in the center of cross-section of petiole. 2 small vascular bundles in the ends of the petiole and sheet cells present around this bundles. The central vascular bundle has 23-25 xylem rays. Diameter of trachea is 5-18 $\mu \mathrm{m}$.

S. multicaulis Vahl: Outermost layer of the petiol is single cell lined epidermis, rectangular or quadrangular shaped. Epidermis cells are $15-50 \mu \mathrm{m}$ in width and 10-18 $\mu \mathrm{m}$ in length. Parenchyma under epidermis has not intercellular space and consist of 8-23 cell layer. Parenchyma cells are oval, roundish or rectangular in shape and 10-20 $\mu \mathrm{m}$ in width, 30-80 in lenght. Multi-lobed 
(5), big vascular bundle is present at the center of the petiole. There is oval shaped 2 vascular bundle in each corner. The central vascular bundle has 83-90 xylem rays. Diameter of trachea is $10-28 \mu \mathrm{m}$.

S. wiedemannii Boiss.: The one layered epidermis is consist of oval and rectangular shaped cells. Epidermis cells are $25-38 \mu \mathrm{m}$ in width and $10-19 \mu \mathrm{m}$ in length. There is a layered eksodermis under the epidermis. Intercellular spaces present in 6-11 cell layered parenchyma under the eksodermis. Parenchyma cells are roundish and hexagonal in shaped and have 20-65 $\mu \mathrm{m}$ diameter. A big vascular bundle is located in the center of cross-section of petiole, while 2 small vascular bundles surrounded by sheat cells in the ends of the petiole. The central vascular bundle has $17-20$ xylem rays. Diameter of trachea is 5-18 $\mu \mathrm{m}$.

S. suffruticosa Montbr. \& Auch.: Epidermis cells are single layered, rectangular or squarish in shaped. Epidermis cells are 10-20 $\mu \mathrm{m}$ in width and 9-14 $\mu \mathrm{m}$ in length. Intercellular spaces absent in 6-10 layered parenchyma. Parenchyma cells are roundish or oval in shaped and $25-63 \mu \mathrm{m}$ in diameter. A big vascular bundle is present in the center and 4 surrounded by sheat cells in the ends of the petiole. The central vascular bundle has $25-28$ xylem rays. Diameter of trachea is 8-20 $\mu \mathrm{m}$.

S. verticillata ssp. amasiaca (Freyn \& Bornm.) Bornm.: Epidermis cells are single layered in cross section of the petiol and rectangular or squarish shaped. Epidermis cells are $10-25 \mu \mathrm{m}$ in width and $12-17 \mu \mathrm{m}$ in length. Single layered eksodermis present under the epidermis. Parenchyma under eksodermis consist of 7-11 cell layer. Intercellular spaced parenchyma cells are circular oval and hexagonal in shaped and 13-23 $\mu \mathrm{m}$ in diameter. A big vascular bundle is present in the center and 8 small vascular bundles, surrounded by sheat cells, in the ends of the petiole. The central vascular bundle has $26-30$ xylem rays. Diameter of trachea is 5-20 $\mu \mathrm{m}$.

S. bracteata Banks \& Sol.: Epidermis cells are single layered, rectangular or squarish shaped. Epidermis cells are $12-28 \mu \mathrm{m}$ in width and 11-18 $\mu \mathrm{m}$ in length. Parenchyma under epidermis consist of 8-10 cell layer. Parenchyma cells are circular or oval in shaped and 30-55 $\mu \mathrm{m}$ in diameter. A big vascular bundle is present in the center and 2 small vascular bundles in the ends of the petiole. The central vascular bundle has $18-20$ xylem rays. Diameter of trachea is $11-20 \mu \mathrm{m}$.

S. cadmica Boiss. var. cadmica: Single layered epidermis cells are shaped flat rectangular. Epidermis cells are $15-25 \mu \mathrm{m}$ in width and 10-15 $\mu \mathrm{m}$ in length. Double layered eksodermis present under the epidermis. Parenchyma under eksodermis consist of 3-5 cell layer. Parenchyma cells are oval and roundish in shaped and $22-45 \mu \mathrm{m}$ in width, $10-21 \mu \mathrm{m}$ in lenght. A big vascular bundle is present in the center and 2 small vascular bundles in the ends of the petiole. The central vascular bundle has 20-23 xylem rays. Diameter of trachea is $5-14 \mu \mathrm{m}$.

S. blepharochlaena Hedge \& Hub.-Mor.: Epidermis cells are squarish and rectangular in shaped an done layered. Epidermis cells are $15-26 \mu \mathrm{m}$ in width and $19-23 \mu \mathrm{m}$ in length. Single layered eksodermis present under the epidermis. Parenchyma under eksodermis have intercellular spaces and consist of 6-10 cell layer. Parenchyma cells are roundish and hexagonal in shaped and 20-55 $\mu \mathrm{m}$ in diameter. A big and two small vascular bundles are present in the center and 4 small vascular bundles in the ends of the petiole. The central big vascular bundle has 13-14 xylem rays. Diameter of trachea is 5-20 $\mu \mathrm{m}$.

S. microstegia Boiss. \& Bal.: Single cell lined epidermis consist of rectangular or quadrangular shaped cells. Epidermis cells are $15-38 \mu \mathrm{m}$ in width and $12-25 \mu \mathrm{m}$ in length. Parenchyma under epidermis has not intercellular space and consist of 10-16 cell layer. Parenchyma cells are oval, roundish, flat or rectangular in shaped and $17-40 \mu \mathrm{m}$ in width, 8-21 in lenght. Multi-lobed (5), big vascular bundle is present at the center of the petiole. There is oval shaped 4 vascular bundle in each corner. The central vascular bundle has $51-55$ xylem rays. Diameter of trachea is 7-16 $\mu \mathrm{m}$. 


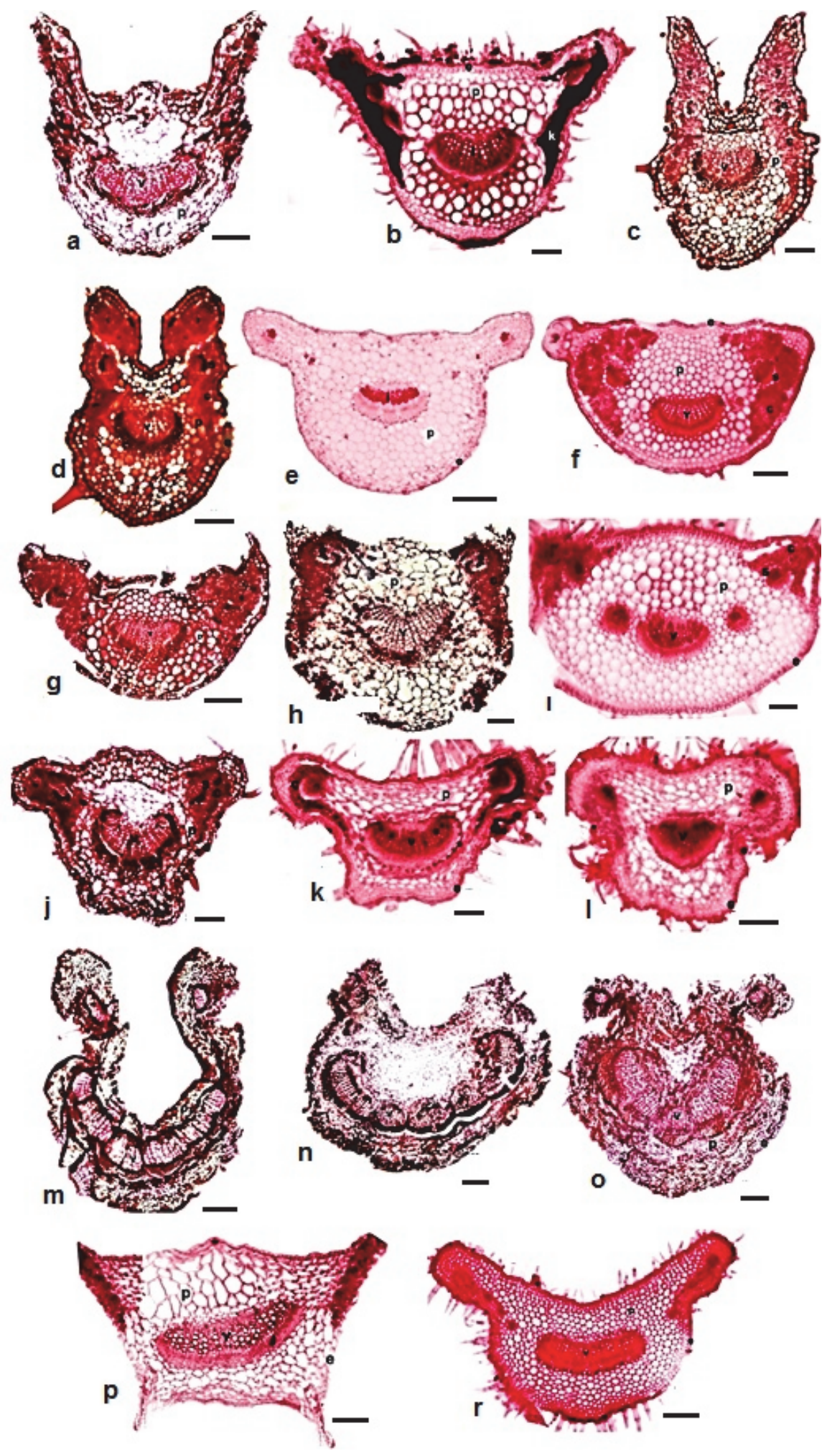

A. S. limbata, B. S. huberi, C. S. verticillata ssp. Verticillata, D. S. chrysophila, E. S. recognita, F. S. Halophila, G. S. smrynaea, H. S. tchihatcheffii, I. S. multicaulis, J. S. wiedemannii, K. S. suffruticosa, L. S. verticillata ssp. Amasiaca, M. S. bracteata, N. S. cadmica, O. S. blepharochlaena, P. S. microstegia, R. S. cryptantha. e. epidermis, p. parenchyma v. vascular bundle c. chlorenchyma.

Figure 1 - Cross-section of the taxa leaves (Scala bar $50 \mu \mathrm{m})$. 

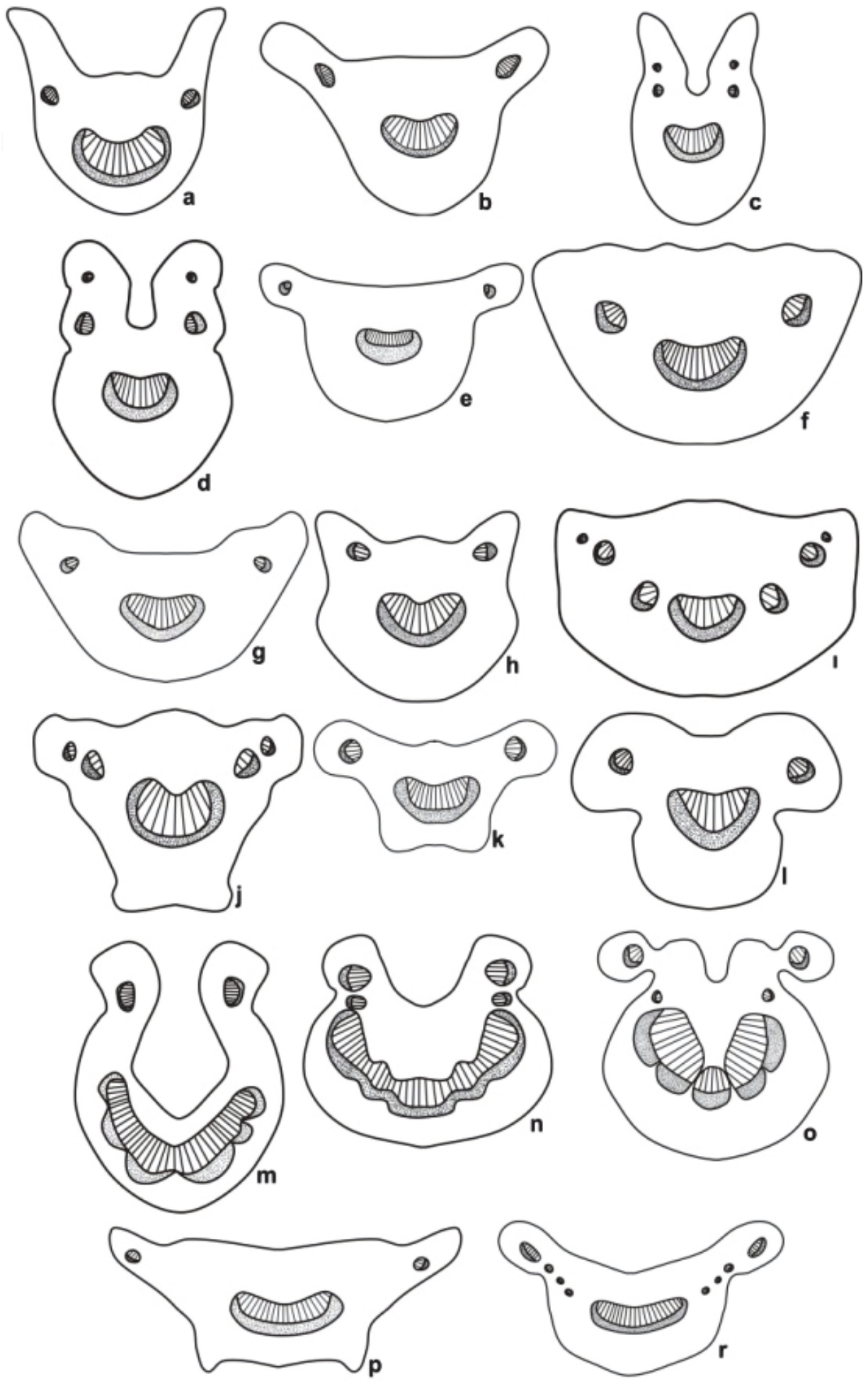

A. S. limbata, B. S. huberi, C. S. verticillata ssp. verticillata, D. S. chrysophila, E. S. recognita, F. S. halophila, G. S. smrynaea, H. S. tchihatcheffii, I. S. multicaulis, J. S. wiedemannii, K. S. suffruticosa, L. S. verticillata ssp. amasiaca, M. S. bracteata, N. S. cadmica, O. S. blepharochlaena, P. S. microstegia, R. S. cryptantha.

Figure 2 - General drawing of petiols and vascular bundles. 
S. cryptantha Montbret \& Aucher ex

Bentham: Rectangular, oval or squarish shaped epidermis cells are single layered in outermost surface of petiol cross section. Epidermis cells are $15-38 \mu \mathrm{m}$ in width and $15-25 \mu \mathrm{m}$ in length. Intercellular spaces absent in 5-7 layered parenchyma. Parenchyma cells are roundish or oval in shaped and $19-40 \mu \mathrm{m}$ in diameter. A big vascular bundle is present in the center and 2 in the ends of the petiole. The central vascular bundle has 20-23 xylem rays. Diameter of trachea is $7-16 \mu \mathrm{m}$ (Figure 1, 2).

The aim of this study was to investigate the anatomical structures of petioles of 17 Salvia taxa growing in Turkey. Anatomical structures of the petiole are very important in family Lamiaceae (Metcalfe and Chalk, 1972). The results showed us that within the studied taxa, there were many differences between the amount and arrangement of vascular bundles, as well as their shapes. Özdemir and Senel (1999) showed the importance of the amount of vascular bundles and its arrangement within the petiole in the Salvia species. Maksymowych et al., (1983) examined petiole anatomy of 26 herbaceous and ligneous taxa and showed that the vascular bundles were positioned differently in each and every different type. Many scientists have also examined other families' petiole vascular bundles. Heneidak et al. (2007) examined 15 different types of the Fabaceae family and showed the importance of the shape of the petioles, the features of the epidermal cells, fibers, crystal types, secretion elements, hairs and the anatomy of the vascular bundles. Other scientists have studied with the Rubiaceae family and have examined the anatomy of the petioles, the structure of the vascular bundles and the hair types and showed the importance it has in terms of taxonomic classification (Kocsis et al., 2004). Olowokudejo (1987) studied the petiole shapes of 46 taxa belonging to the Cruciferae family and reported the differences in the petiole shapes. Anatomical features of petiole can be a more useful way of taxonomic classification.

As shown in Table 3 and Table 5, there are important correlations between S. blepharochlaena, S. multicaulis and S. chrysophila-S. cryptantha which are close
Table 3 - Correlation between 16 investigated Salvia taxa (Regression Analysis)

\begin{tabular}{|c|c|c|c|c|}
\hline Taxon & MS & F-value & Probility & Significicance \\
\hline A-D & 1029.1 & 37.22 & 0.009 & $* *$ \\
\hline A-E & 999.20 & 26.57 & 0.014 & $* *$ \\
\hline$A-G$ & 1029.1 & 37.22 & 0.009 & $* *$ \\
\hline A-I & 849.25 & 9.70 & 0.053 & NS \\
\hline A-L & 848.00 & 9.64 & 0.053 & NS \\
\hline A-M & 1057.6 & 58.32 & 0.005 & $* *$ \\
\hline A-P & 921.67 & 14.53 & 0.032 & $* *$ \\
\hline A-S & 19.980 & 19.98 & 0.021 & $* *$ \\
\hline $\mathrm{B}-\mathrm{C}$ & 519.92 & 58.04 & 0.005 & $* *$ \\
\hline B-R & 503.11 & 34.54 & 0.010 & $* *$ \\
\hline C-J & 179.20 & 16.39 & 0.027 & $* *$ \\
\hline C-P & 199.57 & 48.18 & 0.006 & $* *$ \\
\hline D-E & 199.57 & 48.18 & 0.006 & $* *$ \\
\hline D-H & 1314.6 & 11.95 & 0.041 & $* *$ \\
\hline D-M & 1383.0 & 15.85 & 0.028 & $* *$ \\
\hline $\mathrm{D}-\mathrm{O}$ & 1417.2 & 18.68 & 0.023 & $* *$ \\
\hline D-R & 1565.8 & 59.43 & 0.005 & $* *$ \\
\hline H-M & 1868.4 & 48.47 & 0.006 & $* *$ \\
\hline I-M & 944.03 & 18.30 & 0.023 & $* *$ \\
\hline $\mathrm{I}-\mathrm{O}$ & 1073.3 & 126.4 & 0.002 & $* *$ \\
\hline I-R & 838.29 & 9.65 & 0.053 & $*$ \\
\hline J-P & 220.03 & 21.45 & 0.019 & $* *$ \\
\hline K-N & 106.56 & 9.34 & 0.055 & NS \\
\hline $\mathrm{M}-\mathrm{O}$ & 1041.1 & 24.38 & 0.016 & $* *$ \\
\hline M-R & 892.64 & 9.68 & 0.053 & NS \\
\hline O-R & 1516.9 & 14.50 & 0.032 & $* *$ \\
\hline P-R & 187.67 & 15.00 & 0.030 & $* *$ \\
\hline
\end{tabular}

MS: mean square; NS: not significant; ${ }^{*} \mathrm{P}<.05 ; * * \mathrm{P}<.01$. A-R: Taxon Codes.

Table 4 - Pearson correlation (Correlation) based on 5 anatomical characters of the leaves of the investigated taxa

\begin{tabular}{|c|l|l|l|l|}
\hline $\begin{array}{c}\text { Characters } \\
\text { No. }\end{array}$ & 1 & 2 & 3 & 4 \\
\hline \multirow{2}{*}{2} & 0.362 & & & \\
\cline { 2 - 5 } & 0.140 & & & \\
\hline \multirow{2}{*}{3} & $0.007^{* *}$ & 0.573 & & \\
\cline { 2 - 5 } & 0.979 & $0.013^{* *}$ & & \\
\hline \multirow{2}{*}{4} & $0.007^{* *}$ & 0.483 & 0.749 & \\
\cline { 2 - 5 } & 0.978 & $0.042^{*}$ & $0.001 * *$ & \\
\hline \multirow{2}{*}{5} & $0.029 *$ & 0.194 & 0.430 & $0.030^{* *}$ \\
\cline { 2 - 5 } & 0.910 & 0.441 & 0.075 & 0.906 \\
\hline
\end{tabular}

* Significant at the level of 0.05 . ** Significant at the level of 0.01. 1-5: Character Codes. 
Table 5 - The results of Analysis of Variance among the 10 investigated taxa (Regression Analysis)

\begin{tabular}{|c|r|r|c|c|}
\hline Taxon & \multicolumn{1}{|c|}{ MS } & F- Value & Probability & Significance \\
\hline $1-2$ & 113.12 & 2.42 & 0.140 & NS \\
\hline $1-3$ & 53.89 & 1.16 & 0.007 & $* *$ \\
\hline $1-4$ & 87.20 & 3.97 & 0.007 & $* *$ \\
\hline $1-5$ & 0.17 & 0.01 & 0.029 & $* *$ \\
\hline $2-3$ & 211.24 & 70.81 & 0.013 & $* *$ \\
\hline $2-4$ & 150.12 & 4.86 & 0.042 & $*$ \\
\hline $2-5$ & 24.20 & 0.62 & 0.440 & NS \\
\hline $3-4$ & 260.43 & 20.46 & 0.001 & $* *$ \\
\hline $4-5$ & 42.09 & 0.01 & 0.030 & $*$ \\
\hline
\end{tabular}

MS: mean square; NS: not significant; $* \mathrm{P}<.05 ; * * \mathrm{P}<.01 .1-5$ : Character Codes.

species as systematically. On the other hand there are no important differences between S. suffruticosa and S. cadmica which are close species as systematically. It is mentioned that there are close relationships between S. blepharochlaena, S. multicaulis and S. chrysophila - S. cryptantha (Davis, 1982) Also, according to the statistical results derived, there is a considerable relation between the two taxa, at the level of $\mathrm{P}<0.01$. The results of the statistical analysis were presented in Tables 4 and 6 It was found that there were statistically important differences between element 1-3,1-4, 1-5, 2-3, 4-5 and 3-4 at levels of 0.01P and 0.05P. By the analysis of investigated taxa from five leaf anatomy related characters, it has been determined that epidermis width and Trachea diameter are the best characters pairs which represents the variations in them. It has been also found that the results from nümerical analysis of the leaf anatomy characters can provide distinct evidences, which are corresponding to the anatomy for recognition of the taxa.

\section{REFERENCES}

Agbagwa O.I., Ndukwu B.C. The valve of morphoanatomical features in the systematic of Cucurbita L. (Cucurbitaceae) species in Nigeria. Afr J Biotechnol. 2004;3:541-6.

Akçin Ö., Özyurt S., Şenel G. Petiole anatomy of some Lamiacaea Taxa. J Bot. 2011;43:1437-43.

Algan G. Microtechnics for the Plant Tissues. Publication of Fýrat Univ. Science \& Art Faculty, Istanbul. 1981;1.
Baytop T. Türkiye'de Bitkiler ile Tedavi. Istanbul: Üniv. Yay, 1984. (Serie, 3255)

Davis P.H. Flora of Turkey and the East Aegean Islands. Edinburg: Edinburg University Press, 1982; 400-2. (Serie, 7)

Davis P.H., Mill R.R., Tan K. Flora of Turkey and the East Aegean Islands Edinburg: Edinburg University Press, 1988; 201-10. (Serie, 10)

Doðan M. et al. Türkiye'de yayýlýp gösteren Salvia L. (Labiatae) cinsinin taxonomik revizyonu. 2008. (Tübitak Proje No: 104 T 450)

Dönmez A.A. A new Turkish species of Salvia L. (Lamiaceae) Bot J Linn Soc. 2001;137:413-16.

Duarte M.R. Lopes, J.F. Stem and leaf anatomy of Plectranthus neochilus Schltr., Lamiaceae. Braz J Pharm. 2007;17:549-56.

Güner A. et al. Flora of Turkey and the East Aegean Islands. Edinburg: Edinburg University Press, 2000;197-09. (Serie, 11)

Heneidak S., Samai A., Shaheen M. Characteristics of then proximal to distal regions of the petioles to identify 15 tree species of Papilionoideae-Fabaceae. Bangladesh J Plant Taxonomy. 2007;14:101-15.

Kharazian N. The taxonomy and variation of leaf anatomical characters in the genus Aegilops L. (Poaceae) in Iran. Turk J Bot. 2007;31:1-9.

Kocsis M., Darok J., Borhidi A. Comparative leaf anatomy and morphology of some neotrophical Rondeletia (Rubiaceae) species. Plant Syst Evol. 2004;248:205-18.

Maksymowych A.B., Orkwiszewski A.J., Maksymowych R. Vascular bundles in petioles of some herbaceous and woody dicotyledons. Am J Bot. 1983;70:1289-96.

Metcalfe C.R., Chalk L. Anatomy of Dicotyledons II. Oxford: Clarendon Press, 1972.

Olowokudejo J.D. Taxonomic value of petiole anatomy in the genus Biscutella L. (Cruciferae). Bull Jard Bot Nat Belg. 1987;57:307-20.

Özdemir C., Senel G. The morphological, anatomical and Karyological properties of Salvia sclarae L. Trans J Bot. 1999;23:7-18.

Shaheen A.M, Characteristics of the stem-leaf transitional zone in some species of Caesalpinioideae (Legumuninosae) Turk J Bot. 2007;31:297-10.

Planta Daninha, Viçosa-MG, v. 34, n. 3, p. 465-474, 2016 
Tepe E.J., Vincent M.A., Watson, L.E. The importance of petiole structure on inhabitability by ants in Piper sect.

Macrostachys (Piperaceae). Bot J Linn Soc. 2007;153:181-91.
Vural A., Adigüzel N. A new species from Central Anatolia : Salvia aytachii M. Vural et N.Adýgüzel (Labiatae). Turk J Bot. 1996;20:531-4. 


\section{ERRATUM}

In the article "Statistical comparative petiole anatomy of Salvia sp.", DOI http://dx.doi.org/10.1590/ S0100-83582016340300007, published in the Planta Daninha Journal, volume 34, issue 3.p. 465 to 474 , in the pages 466 and 473 ,

\section{Where you read:}

“...Thus, useful petiole anatomic characters are determined in designated taxonomical structures of some species (Olowokudejo, 1987, Shaheen, 2007, Eric et al., 2007."

"Eric T.J., Michael V.A., Linda, W.E. The importance of petiole structure on inhabitability by ants in Piper sect. Macrostachys (Piperaceae). Bot J Linn Soc. 2007;153:181-91.”

\section{It should be read:}

“...Thus, useful petiole anatomic characters are determined in designated taxonomical structures of some species (Olowokudejo, 1987, Shaheen, 2007, Tepe et al., 2007."

“Tepe E.J., Vincent, M.A., Watson, L.E. The importance of petiole structure on inhabitability by ants in Piper sect. Macrostachys (Piperaceae). Bot J Linn Soc. 2007;153:181-91.” 